Annals of Plant and Soil Research 23(1): 61-65 (2021)

https://doi.org/10.47815/apsr.2021.10030

\title{
Response of French bean (Phaseolus vulgaris I.) to integrated nutrient management on acid alfisol of Nagaland
}

\section{LONGMATULA, S.P. KANAUJIA* AND MOAKALA CHANGKIRI}

\begin{abstract}
Department of Horticulture, School of Agricultural Sciences and Rural Development, Medziphema Campus, Nagaland University, Nagaland- 797106
\end{abstract}

Received: November, 2020; Revised accepted: January, 2021

\begin{abstract}
A field experiment was carried out at Research farm, Department of Horticulture, School of Agricultural Sciences and Rural Development, Nagaland University, Medziphema campus, Nagaland during 2018-2019 to evaluate the effect of integrated nutrient management on growth, yield, quality and economics of French bean (Phaseolus vulgaris $L$ ) under foothill condition of Nagaland. The experiment was laid out in randomized block design with eleven treatments and three replications. Results revealed that the application of different levels of fertilizes, organic manures and biofertilizers either alone or in combination significantly increased the growth, yield and quality of French bean as compared to control. Application of 50\% NPK as inorganics + 50\% vermicompost exhibited maximum plant height $(34.3 \mathrm{~cm})$, branches plant ${ }^{-1}(9.4)$, leaves plant ${ }^{-1}$ (27.3), pods plant $^{-1}(26.3)$, length of pod $(14.9 \mathrm{~cm})$, width of pod $(1.04 \mathrm{~cm})$, seeds pod ${ }^{-1}(7.1)$, fresh weight of pod $(7.1 \mathrm{~g})$, pod yield (246.99 $\left.\mathrm{q} \mathrm{ha}^{-1}\right)$ and crude protein content (28.8\%). There was a significant build up of organic carbon and available nutrients except available nitrogen in post harvest soil with INM practices and maximum values of organic carbon $\left(16.8 \mathrm{~g} \mathrm{~kg}^{-1}\right)$, available $P\left(26.8 \mathrm{~kg} \mathrm{ha}^{-1}\right)$ and available $\mathrm{K}\left(126.8 \mathrm{~kg} \mathrm{ha}^{-1}\right)$ were recorded with $50 \%$ NPK as inorganics $+50 \%$ vermicompost. While maximum value of available nitrogen $\left(297.6 \mathrm{~kg} \mathrm{ha}^{-1}\right)$ in post harvest soil was recorded with $100 \%$ NPK as inorganics. The highest net return of Rs 3, 45,388 ha ${ }^{-1}$ along with cost benefit ratio of 3.04 was recorded in the treatment having $50 \%$ NPK as inorganics + 50\% FYM.
\end{abstract}

Keywords: French bean, INM, growth, yield, quality, economics

\section{INTRODUCTION}

French bean (Phaseolus vulgaris L.) also popularly known as Kidney bean or Snap bean, belongs to the family Leguminosae. It is self pollinated crop and rich in digestible protein (22.9\%), vitamin A and C, folic acid and fiber. It is also rich in minerals like calcium, potassium, iron and phosphorus. It is grown for the tender green pods and dry seeds (Kanaujia et al., 2020). Its production in India is about 1.977 million tonnes with an area of 0.228 million ha giving a productivity of $10.35 \mathrm{t} \mathrm{ha}^{-1}$ (NHB, 2018). In Nagaland, the production is about 5.62 lakh tonnes from an area of 0.47 lakh ha giving a productivity of about $11.96 \mathrm{t} \mathrm{ha}^{-1}$ (Anon., 2018). The North-East region of India is blessed with favorable conditions for cultivation of French bean. Also from the economic point of view, it is a very profitable crop especially in Nagaland as it fetches the highest price in the market among the pulses and is highly consumed by the people of this region which might be one of the factors responsible for this high price. But inspite of the favourable agro-climatic conditions, production level is low due to lack of proper package of practices. Among various factors responsible for low production of French bean, nutrition is of prime importance. French bean responds very well to nutrients application. However, measures taken regarding the nutrient management practices of this crop are very negligible and not much has been done for this important crop. The aim of integrated nutrient management is to integrate the use of natural and man made soil nutrients to increase crop productivity and preserve soil productivity for future generation. Long term studies on crops indicated that the balanced use of NPK fertilizers could not maintain the higher yields over years because of emergence of secondary and micro-nutrient deficiencies and deterioration of soil physical properties. The increased use of fertilizers no doubt increases production of vegetables remarkably but it has a long-term detrimental impact on soil health. Soil fertility as well as economic return can be improved on sustainable basis by supplying all the nutrients in judicious way if INM approaches are followed (Moakala et al., 2017). Hence, this present study was 
conducted to study the effect of integrated nutrient management on growth, yield and quality of French bean within the prevailing condition of Nagaland.

\section{MATERIALS AND METHODS}

A field experiment was carried out during 2018-2019 at the Research farm, Department of Horticulture, School of Agricultural Sciences and Rural Development, Nagaland University, Medziphema campus, Nagaland. It is situated at an altitude of $310 \mathrm{~m}$ above mean sea level and geographically positioned at $25^{\circ} 45^{\prime} 43^{\prime \prime}$ North latitude and $93^{\circ} 53^{\prime} 04^{\prime \prime}$ East longitude in the foothill of Nagaland.The site of experimental area enjoys a sub-humid tropical climate with high relative humidity $(70-80 \%)$, moderate temperature $\left(12-32^{\circ} \mathrm{C}\right)$ and moderate to high rainfall $(2000-3000 \mathrm{~mm})$. The soil of the experimental site was sandy loam in texture having soil $\mathrm{pH}$ of 4.2 , organic carbon $(14.1 \mathrm{~g} \mathrm{~kg}$ $\left.{ }^{1}\right)$, available $N\left(283 \mathrm{~kg} \mathrm{ha}^{-1}\right)$, available $P(23 \mathrm{~kg}$ $\left.\mathrm{ha}^{-1}\right)$ and available $\mathrm{K}\left(106 \mathrm{~kg} \mathrm{ha}^{-1}\right)$. The experiment was laid out in RBD with three replications. The treatments consisted of $T_{1}$ $100 \%$ NPK as inorganics, $\mathrm{T}_{2} 75 \%$ NPK as inorganics $+25 \% \quad \mathrm{FYM}, \mathrm{T}_{3} 75 \% \quad \mathrm{NPK}$ as inorganics $+25 \%$ pig manure, $\mathrm{T}_{4} 75 \% \mathrm{NPK}$ as inorganics $+25 \%$ vermicompost, $\mathrm{T}_{5} 50 \%$ NPK as inorganics + 50\% FYM, $\mathrm{T}_{6} 50 \%$ NPK as inorganics $+50 \%$ pig manure, $\mathrm{T}_{7} 50 \%$ NPK as inorganics $+50 \%$ vermicompost, $\mathrm{T}_{8} 25 \%$ NPK as inorganics $+75 \%$ FYM + Azotobacter, T925\% NPK as inorganics $+75 \%$ pig manure + Azotobacter, $\mathrm{T}_{10} 25 \%$ NPK as inorganics $+75 \%$ vermicompost + Azotobacter and $\mathrm{T}_{11}$ Control. Sowing of seeds of French bean var. Anupam Gold was done on $26^{\text {th }}$ October, 2018 with spacing of $50 \times 15 \mathrm{~cm}$. Recommended dose of $\mathrm{N}, \mathrm{P}$ and $\mathrm{K}\left(50: 75: 75 \mathrm{~kg} \mathrm{ha}^{-1}\right.$ respectively) were applied through urea, single super phosphate and muriate of potash. Full dose of manures, $\mathrm{P}$, $\mathrm{K}$ and half dose of $\mathrm{N}$ were applied at the final land preparation. The remaining half dose of $\mathrm{N}$ was applied 30 days after sowing. Biofertilizer (Azotobacter) was drenched @ $20 \mathrm{~g} \mathrm{litre}^{-1}$ of water 15 days after sowing. Other recommended package of practices was followed to raise a good crop. The treatments were evaluated on the basis of growth, yield and quality attributes, soil fertility status and economics. Soil samples collected after harvest of the crop were analyzed for $\mathrm{pH}$, organic carbon, available nitrogen, phosphorus and potassium as per standard procedures (Jackson, 1973). The statistical analysis was carried out as per procedure given by Panse and Sukhatme (1989). Economics of the treatments was calculated as per prevailing market price of input and output.

\section{RESULTS AND DISCUSSION}

\section{Growth attributes}

Integrated use of fertilizers, organic manures and biofertilizers alone or in combination was found to have significant effect on growth characters as compared to control (Table 1). Growth behaviour under all the treatments varied considerably and application of $50 \%$ NPK as inorganics $+50 \%$ vermicompost $\left(\mathrm{T}_{7}\right)$ recorded maximum plant height $(34.3 \mathrm{~cm})$, branches plant $^{-1}$ (9.4) and leaves plant $^{-1}(27.3)$. The lowest values of these growth characters were recorded with control. The vermicompost improved the physical, chemical and biological properties of soil which helps in better nutrient absorption and utilization by plants resulting better plant growth. The reason might be due to higher availability of nutrients as a result of integration of organic and inorganic sources. Similar results were also reported by Shwetha et al. (2012) and Zahida et al. (2016).

\section{Yield and yield attributes}

Integrated use of fertilizers and organic manures significantly increased yield and yield attributing characters of French bean compared to control (Table1). Application of $50 \%$ NPK as inorganics $+50 \%$ vermicompost $\left(T_{7}\right)$ recorded maximum values of all yield attributing characters such as pods plant ${ }^{-1}$ (26.3), length of pod $(14.9 \mathrm{~cm})$, width of pod $(1.04 \mathrm{~cm})$, seeds $\operatorname{pod}^{-1}(7.1)$ and fresh weight of pod $(7.1 \mathrm{~g})$. The lowest values of yield attributing characters were recorded with control. Higher vegetative growth under integrated use of nutrients might have helped in synthesis of greater amount of food material which was later translocated into developing pod, resulting in increased pod length and diameter. Integrated use of organic manure and fertilizers increased the availability of NPK and also improved the fertility status of soil and productivity due to which yield attributing 
characters might have increased. Besides NPK, micronutrients might have played an important role in increasing the yield attributing characters of French bean as addition of vermicompost increased the availability of micronutrients. Highest pod yield (246.99 q ha ${ }^{-1}$ ) was recorded with $50 \%$ NPK as inorganics $+50 \%$ vermicompost $\left(T_{7}\right)$ closely followed by $25 \%$ NPK as inorganics $+75 \%$ vermicompost $(236.31 \mathrm{q}$ ha $\left.{ }^{1}\right)$. The integrated use of fertilizers and vermicompost improved the physical properties of soil (water and nutrient holding capacity). Availability of nutrient helps the plants to bear more number of flowers and reduce the chance of flower and fruit drop; as a result, more pods plant $^{-1}$. Similar results were observed by Shwetha et al. (2012) and Zahida et al. (2016).

Table 1: Effect of INM on growth, yield and quality attributes of French bean

\begin{tabular}{|c|c|c|c|c|c|c|c|c|c|c|}
\hline Treatments & $\begin{array}{c}\text { Plant } \\
\text { height } \\
(\mathrm{cm})\end{array}$ & $\begin{array}{l}\text { Branches } \\
\text { plant }^{-1}\end{array}$ & $\begin{array}{l}\text { Leaves } \\
\text { plant }^{-1}\end{array}$ & $\begin{array}{l}\text { Pods } \\
\text { plant }^{-1}\end{array}$ & $\begin{array}{c}\text { Length } \\
\text { of pod } \\
(\mathrm{cm})\end{array}$ & $\begin{array}{c}\text { Width of } \\
\text { pod } \\
(\mathrm{cm})\end{array}$ & $\begin{array}{c}\text { Seeds } \\
\text { pod }^{-1}\end{array}$ & $\begin{array}{l}\text { Fresh } \\
\text { weight of } \\
\text { pod }(\mathrm{g})\end{array}$ & $\begin{array}{c}\text { Pod } \\
\text { yield } \\
\left(\mathrm{q} \mathrm{ha}^{-1}\right)\end{array}$ & $\begin{array}{c}\text { Crude } \\
\text { protein } \\
\text { content }(\%) \\
\end{array}$ \\
\hline $\mathrm{T}_{1}$ & 29.5 & 9.3 & 27.0 & 22.4 & 12.2 & 0.90 & 6.5 & 6.3 & 190.81 & 28.3 \\
\hline $\mathrm{T}_{2}$ & 31.6 & 8.8 & 27.0 & 24.8 & 12.6 & 0.93 & 6.7 & 6.3 & 211.60 & 27.8 \\
\hline $\mathrm{T}_{3}$ & 28.1 & 8.2 & 25.8 & 22.0 & 11.9 & 0.88 & 6.0 & 6.2 & 184.53 & 26.9 \\
\hline $\mathrm{T}_{4}$ & 34.3 & 8.8 & 27.1 & 25.8 & 14.3 & 1.00 & 7.1 & 7.0 & 236.31 & 27.3 \\
\hline $\mathrm{T}_{5}$ & 33.9 & 8.0 & 26.1 & 21.9 & 12.5 & 0.93 & 6.0 & 6.5 & 191.09 & 27.1 \\
\hline $\mathrm{T}_{6}$ & 33.9 & 7.6 & 25.1 & 21.4 & 12.3 & 0.92 & 6.0 & 6.1 & 172.14 & 27.2 \\
\hline $\mathrm{T}_{7}$ & 34.3 & 9.4 & 27.3 & 26.3 & 14.9 & 1.04 & 7.1 & 7.1 & 246.99 & 28.8 \\
\hline $\mathrm{T}_{8}$ & 27.5 & 7.6 & 25.4 & 21.6 & 12.4 & 0.91 & 6.0 & 6.3 & 183.14 & 26.2 \\
\hline $\mathrm{T}_{9}$ & 28.7 & 7.5 & 25.2 & 22.0 & 12.0 & 0.84 & 6.3 & 6.2 & 184.93 & 25.5 \\
\hline $\mathrm{T}_{10}$ & 31.9 & 8.0 & 25.8 & 26.1 & 13.5 & 0.98 & 7.0 & 6.5 & 228.17 & 26.9 \\
\hline $\mathrm{T}_{11}$ & 23.1 & 7.3 & 24.2 & 18.4 & 11.9 & 0.80 & 6.0 & 6.0 & 150.64 & 25.3 \\
\hline SEm \pm & 2.25 & 0.27 & 0.50 & 1.02 & 0.48 & 0.04 & 0.06 & 0.15 & 8.08 & 0.54 \\
\hline C.D. $(P=0.05)$ & 6.64 & 0.79 & 1.48 & 3.00 & 1.42 & 0.11 & 0.19 & 0.44 & 23.83 & 1.60 \\
\hline
\end{tabular}

\section{Quality attributes}

It is evident from Table 1 that various treatments showed appreciable impact on enhancing the protein content in seeds over control. Thus, highest crude protein content $(28.8 \%)$ was recorded with $50 \%$ NPK as inorganics $+50 \%$ vermicompost $\left(\mathrm{T}_{7}\right)$ closely followed by $100 \%$ NPK as inorganics $(28.3 \%)$. The lowest protein content (25.3\%) was recorded with control. The protein improvement could be due to enhancement of nitrogen concentration in seeds with INM (Kumar et al. 2009).

\section{Fertility status of soil}

Sustainability of a cropping system is being evaluated on the basis of crop yield as well as nutrient status of the post harvest soil. Available NPK, organic carbon and $\mathrm{pH}$ were significantly influenced by the application of NPK fertilizers, organic manures and biofertilizers alone or in combination over control (Table 2). Maximum amount of available nitrogen $(297.6 \mathrm{~kg}$ ha $^{-1}$ ) was recorded with application of $100 \%$ NPK as inorganics $\left(T_{1}\right)$, which might be due to poor soil physical structure, lack of organic manures and microbial activities, thus resulting in poor utilization of nitrogen by plants. As such the applied $\mathrm{N}$ could bring about higher residual nitrogen in soil after harvest. However, before experimentation available nitrogen was $283 \mathrm{~kg}$ $\mathrm{ha}^{-1}$.On the other hand, applicationof ${ }_{50} \%$ NPK as inorganics $+50 \%$ vermicompost $\left(T_{7}\right)$ recorded highestavailable phosphorus $\left(26.8 \mathrm{~kg} \mathrm{ha}{ }^{-1}\right)$, potassium (126.8 $\mathrm{kgha}^{-1}$ ) and organic carbon $\left(16.8 \mathrm{~g} \mathrm{~kg}^{-1}\right)$ and soil $\mathrm{pH}$ (4.2). These findings are in line with the researches done by Masanta and Biswas (2009).

\section{Economics}

It is evident from Table 1 that highest net return of Rs $3,45,388 \mathrm{ha}^{-1}$ along with cost benefit ratio of 3.04 was recorded from the treatment of $50 \%$ NPK as inorganics + 50\% FYM $\left(\mathrm{T}_{5}\right)$. The high profitability may be due to lower cost of FYM (Kamble et al. 2016). 
Table 2: Effect of INM on nutrient status of soil after harvest of French bean

\begin{tabular}{|c|c|c|c|c|c|c|c|}
\hline Treatments & $\begin{array}{l}\text { Avail. N } \\
\left(\mathrm{kg} \mathrm{ha}^{-1}\right)\end{array}$ & $\begin{array}{c}\text { Avail. } P(\mathrm{~kg} \\
\left.\mathrm{ha}^{-1}\right)\end{array}$ & $\begin{array}{l}\text { Avail. K } \\
\left(\mathrm{kg} \mathrm{ha}^{-1}\right)\end{array}$ & $\begin{array}{c}\text { Org. } \\
\text { Carbon } \\
\left(\mathrm{g} \mathrm{kg}^{-1}\right)\end{array}$ & $\begin{array}{l}\text { Soil } \\
\mathrm{pH}\end{array}$ & $\begin{array}{l}\text { Net income } \\
\left(\text { Rs ha }^{-1}\right)\end{array}$ & $\begin{array}{l}\text { Cost } \\
\text { benefit } \\
\text { ratio }\end{array}$ \\
\hline $100 \%$ NPK as inorganics & 297.6 & 26.1 & 126.6 & 16.3 & 4.2 & 275831.35 & 2.61 \\
\hline $\begin{array}{l}75 \% \text { NPK as inorganics+ } 25 \% \\
\text { FYM }\end{array}$ & 287.1 & 26.0 & 126.2 & 16.2 & 4.1 & 318389.96 & 2.68 \\
\hline $75 \%$ as inorganics $+25 \% \mathrm{PM}$ & 287.6 & 26.0 & 126.5 & 15.4 & 4.1 & 264042.41 & 2.51 \\
\hline $\begin{array}{l}75 \% \text { NPK as inorganics+ } 25 \% \\
\text { VC }\end{array}$ & 285.6 & 25.9 & 123.0 & 15.7 & 4.1 & 276420.23 & 2.00 \\
\hline $\begin{array}{l}50 \% \text { NPK as inorganics+ } 50 \% \\
\text { FYM }\end{array}$ & 285.5 & 24.8 & 122.9 & 15.7 & 4.0 & 345388.52 & 3.04 \\
\hline $50 \%$ NPK as inorganic $+50 \%$ PM & 285.5 & 25.1 & 122.9 & 15.9 & 4.1 & 239436.79 & 2.28 \\
\hline $\begin{array}{l}50 \% \text { NPK as inorganics+ } 50 \% \\
\text { VC }\end{array}$ & 286.1 & 26.8 & 126.8 & 16.8 & 4.2 & 278480.90 & 2.21 \\
\hline $\begin{array}{l}25 \% \text { NPK as inorganics }+75 \% \\
\text { FYM+ Azot }\end{array}$ & 285.1 & 24.2 & 121.4 & 16.1 & 4.1 & 263403.28 & 2.43 \\
\hline $\begin{array}{l}25 \% \text { NPK as inorganics }+75 \% \\
\text { PM+ Azot }\end{array}$ & 285.2 & 24.7 & 121.4 & 15.5 & 4.1 & 263493.01 & 2.48 \\
\hline $\begin{array}{l}25 \% \text { NPK as inorganics }+75 \% \\
\text { VC + Azot }\end{array}$ & 287.8 & 24.7 & 121.8 & 15.6 & 4.1 & 177326.80 & 0.60 \\
\hline Control (no fertilizer) & 277.1 & 21.5 & 103.5 & 14.7 & 4.0 & 163654.31 & 1.36 \\
\hline SEm \pm & 1.36 & 0.49 & 0.89 & 0.03 & 0.03 & - & - \\
\hline C.D. $(P=0.05)$ & 4.01 & 1.46 & 2.62 & 0.10 & 0.09 & - & - \\
\hline
\end{tabular}

$\overline{P M}=$ poultry manure, $V C=$ vermicompost, Azot $=$ Azotobacter

The lowest BCR (0.60) was recorded with $\mathrm{T}_{10} \quad(25 \% \quad \mathrm{NPK}$ as inorganics $+75 \%$ vermicompost + Azotobacter). The high expenditure in treatment $T_{10}$ might be due to the high cost of vermicompost. The result is in agreement with the findings of Kumar et al. (2009), Kanaujia and Daniel (2016) who reported highest net returns with combined application of $50 \% \mathrm{NPK}+50 \%$ pig manure + biofertilizers.

Based on the present findings, it may be concluded that integrated use of $50 \%$ NPK

\section{REFERENCES}

Anonymous (2018) Economic survey of Nagaland.Directorate of Horticulture, Ministry of Agriculture, Nagaland.

Jackson, M.L. (1973) Soil Chemical Analysis.Prentice Hall of India Pvt. Ltd., New Delhi.

Kamble, M.Y., Kalalbandi, B.M., Kadam, A.R. and Rohidas S.B. (2016) Effect of organic and inorganic fertilizers on growth, green pod yield and economics of French bean (Phaseolus vulgaris L.) cv. HPR35.Legume Research-An International Journal 39 (1): 110-113. through inorganic source $+50 \%$ vermicompost produced the higher pod yield with quality produce under Nagaland conditions. While application of $50 \%$ NPK as inorganics $+50 \%$ FYM was the best in terms of economics. By adopting this treatment, $50 \%$ chemical fertilizers can be saved without any adverse effect on yield, quality and fertility of soil.

Kanaujia, S.P., Maiti, C.S. and Narayan, R. (2020) Text Book of Vegetable Production, Today and Tomorrow Printers and Publishers, New Delhi.

Kanaujia, S.P. and Daniel, M.L. (2016) Integrated nutrient management for quality production and economics of cucumber in acid alfisol of Nagaland. Annals of Plant and Soil Research 18(4):375-380.

Kumar, R. P., Singh, O.N., Singh, Y., Dwivedi, S. and Singh, J.P. (2009) Effect of integrated nutrient management on growth, yield, nutrient uptake and 
economics of french bean (Phaseolus vulgaris L.). Indian Journal of Agricultural Sciences 79 (2): 122-128.

Masanta, S. and Biswas, S. (2009) Effect of various nutrient management practices on productivity, soil fertility status and water use efficiency of french bean grown under homestead condition in Nadia district of West Bengal. Journal of Crop and Weed 5 (2): 50-52.

Moakala, Chankija, Kanaujia, S.P., Jha Aastik, Sema, A. and Maiti, C.S. (2017) Effect of integrated nutrient management on growth, yield and quality of broccoli (Brassica oleracea var italic L.) cv, Calabrase under foothill condition of Nagaland. Vegetable Science 44(1):4753.
NHB.(2018) Indian Horticulture Database. National Horticulture Board, Gurgaon, Haryana.

Panse, V. G. and Sukhatme, P.V. (1989) Statistical Methods for Agricultural Workers. ICAR, New Delhi.

Shwetha, S., Narayana, J., Shwetha, B. V. and Nirmala, P. (2012) Influence of integrated nutrient management on growth and yield parameters of french bean. Mysore Journal of Agricultural Sciences 46 (3): $655-657$.

Zahida, R., Shahid, Dar B., Mudasir R., Inamullah, S. and Rakshanada A. (2016) Morphological, yield and soil quality studies of French bean (Phaseolus vulgaris L.) as influenced by integrating various organic and inorganic fertilizers. The Bioscan 11 (1): 573-577. 